\title{
Klippel-Trenaunay syndrome - a promising role of sirolimus? Case report
}

\author{
DIgor Tagasovski*, \\ (iD)Andrea Crkvenac \\ Gregorek, \\ (D) Sanda Huljev Frković, \\ (D)Dražen Perkov, \\ (D)Majda Vrkić \\ Kirhmajer
}

University of Zagreb School of Medicine, University Hospital Centre Zagreb, Zagreb, Croatia
RECEIVED:

December 4, 2020

ACCEPTED:

December 18, 2020

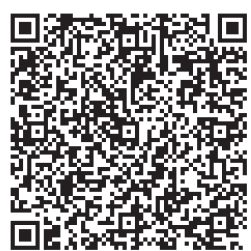

KEYWORDS: Klippel-Trenaunay syndrome, congenital malformation, sirolimus. CITATION: Cardiol Croat. 2021;16(1-2):73. | https://doi.org/10.15836/ccar2021.73

*ADDRESS FOR CORRESPONDENCE: Igor Tagasovski, Klinički bolnički centar Zagreb, Kišpatićeva 12, HR-10000 Zagreb, Croatia. / Phone: +385-95-5690612 / E-mail: i.tagasovski@hotmail.com

ORCID: Igor Tagasovski, https://orcid.org/0000-0001-9221-6762 • Andrea Crkvenac Gregorek, https://orcid.org/0000-0002-7790-1347 Sanda Huljev Frković, https://orcid.org/0000-0003-1513-2965 • Dražen Perkov, https://orcid.org/0000-0001-5398-059X Majda Vrkić Kirhmajer, https://orcid.org/0000-0002-1340-1917

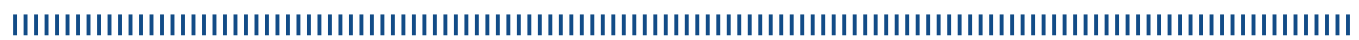

Introduction: Klippel-Trenaunay Syndrome (KTS) is rare syndrome characterized by a presence of capillary and venous malformation, limb overgrowth, with or without lymphatic anomalies ${ }^{1}$. KTS is related to mutations in the PIK3CA gene. Complications of KTS include clotting disorder, bleeding, lymphedema, soft tissue infection and pain. Treatment is individualized; it may include endovascular or surgical procedures and supportive care (management of coagulopathy, infection, pain). The use of mammalian target of rapamycin (mTOR) inhibitor sirolimus shows promising results in complex vascular malformations ${ }^{2,3}$.

Case report: We present a 45 years old patient, currently living out of Croatia. Vascular malformation of the left arm was noticed a few months after his birth. During his childhood an angiography of the left arm lead to confirmation of KTS without further specific treatment. During the last 15 years he was undergoing regular hematology controls and treatment of consumptive coagulopathy as complication of KTS. In 2010 at age 35, he suffered a fracture on the left arm, but he was declared inoperable on basis of vascular malformation which extended the healing process. From 2018 further proliferation of vascular malformation was noticed on his left hemithorax. In 2020 he was presented to multidisciplinary vascular team, MR angiography was performed Unfortunately, due to extreme extension of vascular malformation with soft tissue hypertrophy and osseous deformation the patient is not suitable for any surgical or endovascular procedure. We suggested a treatment with sirolimus which is delayed due to patient's temporary relocation. Genetic panel testing covering PIK3CA gene is in progress.

Conclusion: By presenting this case, our objective is to increase the awareness of KTS, related complications and the role of sirolimus which can improve the prognosis of vascular anomalies. Additionally, we wish to emphasize the importance of multidisciplinary vs specialty focused approach in management patients with KTS.

LITERATURE IIIIIIIIIIIIIIIIIIIIIIIIIIIIIIIIIIIIIIIIIIIIIIIIIIIIIIIIIIIIIIIIIIIIIIIIIIIIIIIIIIIIIIIIIIIIIIIIII

1. Wassef M, Blei F, Adams D, Alomari A, Baselga E, Berenstein A, et al; ISSVA Board and Scientific Committee. Vascular Anomalies Classification: Recommendations From the International Society for the Study of Vascular Anomalies. Pediatrics. 2015 Jul;136(1):e203-14. https://doi.org/10.1542/peds.2014-3673

2. Hammer J, Seront E, Duez S, Dupont S, Van Damme A, Schmitz S, et al. Sirolimus is efficacious in treatment for extensive and/or complex slowflow vascular malformations: a monocentric prospective phase II study. Orphanet J Rare Dis. 2018 0ct 29;13(1):191. https://doi.org/10.1186/s13023-018-0934-z

3. Freixo C, Ferreira V, Martins J, Almeida R, Caldeira D, Rosa M, Costa J, Ferreira J. Efficacy and safety of sirolimus in the treatment of vascular anomalies: A systematic review. J Vasc Surg. 2020 Jan;71(1):318-327. https://doi.org/10.1016/j.jvs.2019.06.217 